JOURNAL OF SECURITY AND SUSTAINABILITY ISSUES

ISSN 2029-7017 print/ISSN 2029-7025 online

2020 March Volume 9 Number 3

https://doi.org/10.9770/jssi.2020.9.3(11)

Scopus

\title{
IMPACT OF CURRENCY REGIME ON BUSINESS COMPANIES: PERCEPTION OF GEORGIA'S BUSINESSMEN
}

\author{
Nodar Chinchaladze \\ University of Georgia (UG), Merab Kostava Str. 77, Tbilisi 0171, Georgia \\ E-mail:amioni@amioni.ge
}

Received 13 February 2019; accepted 12 December 2019; published 30 March 2020

\begin{abstract}
Clearly money is very important for any community of humans, especially for business purposes. It is well known that in modern world currencies of all developed countries have their own problems but problems of coping with own currency is much bigger in developing countries. Steve Hanke offers fixed exchange rate as a solution for developing countries. There can be some other ways too: not to have national currency, to have free currency regime, etc. Here is given a research about the currency problems of Georgian businessmen and of their opinions about how one could better cope with the currency's problems.
\end{abstract}

Keywords: business development; stability; value of money; durability of money; devaluation

Reference to this paper should be made as follows: Chinchaladze, N. 2020. Impact of currency regime on business companies: perception of Georgia's businessmen. Journal of Security and Sustainability Issues, 9(3), 853-868. https://doi.org/10.9770/jssi.2020.9.3(11)

JEL Classification: E000, E310, F310, G380, M210

\section{Introduction}

Money is one of the main tools in the economy. There is a lot of attention to various facets of money functioning, to be it innovative forms of money, money laundering, factors affecting value of local currencies etc. (e.g. Šimonová et al, 2019; Kordík, Kurilovská, 2017; financing, Baltgailis, J. 2019; Humbatova et al., 2019; Limba et al., 2019). Monetary policies allow to tackle such issues as unemployment, poverty, to impact economic growth patterns. Monetary policy directly affects conditions of entrepreneurship.

The presented paper aims to reveal reaction of Georgia's business companies to diminishing value of national currency and their opinions about country's monetary policy alternatives, which will be faced in the near future.

\section{Context of the research.}

Looking at the history of money it seems that the best period was the one with golden standard, not ideal but better than we have now. All the time there were some supporters of golden standard but as Josef Salerno writes: "As recently as the early 1970s, the prospect of a governmental body seriously deliberating the merits of reinstituting the gold standard would have been considered unthinkable. In the years following World War II, the overwhelming majority of economists and economic policymakers as well as the population at large came increasingly to consider gold as a relic of a barbarous and bygone age, unfit to perform the functions of money in a modern industrial economy. The tiny handful of gold standard advocates, both inside and outside the economics profession, were then regarded as hopelessly benighted economic Neanderthals or thralls to a peculiar fetish" (Salerno, 2010, p. 324). 
It is clear that money which is manipulated by someone (government) is not sound, it cannot be sound when its value depends on political expediency. During centuries people understanding this problem tried to find its solution. Salerno writes: "The idea of sound money was present from the very beginning of modern monetary theory in the works of the sixteenth-century Spanish Scholastics who argued against debasement of the coinage by the king on ethical and economic grounds. The concept of sound money, or "sound currency" as it was then called, was central to the writings of David Ricardo and his fellow "bullionists" in the early nineteenth century who argued that the price inflation observed in Great Britain during and after the Napoleonic Wars was caused by the suspension of the convertibility of bank notes into gold and silver mandated by the British government. The ideal of the bullionists was "a self-regulating currency" whose quantity, value and distribution among nations were governed exclusively by market forces of supply and demand" (Salerno, 2010, p. xi).

It is clear that the stability of money is very important for economic subjects, for making any contract it is very important that 100 dollars today is equal to tomorrow's 100 dollars. Without this stability there appear problems with making long term agreements and this delays economy. John Maynard Keynes did understand this mentioning that inflation is method of taxation. However not business subjects and their activity were important for him but the government: "A Government can live for a long time, even the German Government or the Russian Government, by printing paper money. That is to say, it can by this means secure the command over real resources, - resources just as real as those obtained by taxation. The method is condemned, but its efficacy, up to a point, must be admitted. A Government can live by this means when it can live by no other. It is the form of taxation which the public hind hardest to evade and even the weakest Government can enforce, when it can enforce nothing else" (Keynes, 1924, p. 41). But the question is if this is better either for the business subjects, or for the business activities, or for the economy. What is better for the nation, wealthy government or more activity of business subjects?

Many authors wrote about this problem in USA showing the problem of US Dollar with Federal Reserve System (FRS) and trying to find way out from this blind alley. For example, Milton Friedman says that the FRS turned to a stubborn institution... (Friedmen, 2002, p. 44) and he thinks that the range of FRS should be limited to print money (make emission) by range 3-5\% (Friedmen, 2002, p. 54). Because of his understanding the problem with FRS he emphasized impropriety of supporters' mind. For example, after every crisis the supporters claimed that this crisis could be much worse if not the attempts of FRS. Friedman writes that all these arguments are wrong. The fact is that depression and partially also other periods of unimploiments are the results of wrong steps of government and not result of non-stability of private sector of the economy. The responsibility was given to the agency - Federal Reserve System which was established by government. And this agency in years 1930 and 1931 attained that the problem which in other case could be small recession of economics became to a huge catastrophe. (Friedmen, 2002, p. 39).

While arguments by gold standard proponents are increasingly serious in light of the current problems, there seems to be no sign that the dispute will reach a consensus in the near future. Even Alan Greenspan himself (who later served as chairman of the US Federal Reserve System for all 19 years, from 1987-2006) states: "This is the secret of the welfare state against the faded secret of gold. Deficit spending is a simple scheme of 'hidden' wealth seizure. On the way to this insidious process lies gold as a proponent of property rights. If each of us embraces this insidious plan, it will not be difficult to imagine the aggression of those who advocate state intervention against the gold standard". (Greenspan, 2010, p. 147). He compares the system before the First World War (before the Federal Reserve System which was istablished in 1913 there was the gold standard regime) and the current one with a clear indication of how much worse the new system to overcome the crisis: "a completely free banking system and the gold standard of the system so far has not been achieved. But before World War I, the banking system in the United States (and many countries around the world) was based on gold, and although governments sometimes intervened, banks were more free than controlled. Periodically, as loans expanded rapidly, banks lent below their gold reserves limit, new loans ceased to generate sharp increases in yields, and the economy was in a sharp but short recession (compared to the Depression of the 1920s and 1932, production declines were moderate until World War I). It was limited by the availability of gold reserves, which 
prevented an unbalanced expansion of production activity. The transition periods were short and the economy was quickly restoring a reliable base for expansion.” (Greenspan, 2010, p. 145).

Shortly, the government spending is giving illusion that it can hurry up an economic growth. Hayek says: "The origins of contemporary monetary problems related to Keynes and his disciples, who have given scientific power to centuries old prejudice about that spending money gives long-term prosperity and achieving full employment". (Hayek, 2016).

The current situation is that each economic entity has to constantly take into account the inflation factor, but this was not so during the history of humanity, as "for centuries tobacco, wheat, non-ferrous metals, sheep, etc., played a role of money in various societies. However, gold and silver have been the most well-loaded functions of money. Most states speaking in different languages recognized the advantage of using gold money, compared to other commodities that made gold (and partly silver) a world currency many centuries ago. The public has never had a need for modern monetary policy, as inflation in the money market has never bothered the public despite the fact that the banking system was free from any central bank pressure and restrictions. Inflation is the result of excess of money, and the bank itself is a source of additional money" (Tsomaia, 2010, p. 218).

There are much more radical views from some other scientists. For example, Hans-Hermann Hoppe thinks that the emission of printed money means to put fiat money in the turnover and only the ones get profit from this emission who get the new printed money at first (Hoppe, 2010, p. 173).

While the problem exists for developed countries like USA and others, the same problem is much bigger for the developing ones. Different countries have different currency regimes and mostly the problems occur because of these regimes. National bank of each country tries to argue that the current system for their country is most appropriate and it should be as it is. In Georgia there is free floating regime and Georgian national bank argues that this is the best one for Georgia. Tamar Baiashvili analyses some circumstances and concludes that: "current floating regime for Georgian economy is optimal" (Baiashvili, 2018, p. 59).

Opposite to the national bank's position there are scientists who think that it would be much better if developing countries used foreign stable currencies as theirs or at least to fix national currencies' exchange rates to one of them or to their combination. Steve Hanke even wrote a special book for Georgia to help to change Georgian national bank to the currency board of Georgia. In this book he wrote: "dollarization is much more transparent, trustable and profitable for the economy..." (Hanke Steve, 2010, p. 39).

Another issue needs to be emphasized. It is widely believed that reducing the value of a currency against foreign currencies is good for the economy as it promotes export. In fact: "The encouragement of export by depreciating means of payment directly means giving a benefit to the population of the importing country at the expense of own population (the same economic entities N.Ch.) - the local population is already buying less through their depreciated means of payment, and foreigners have a more chance to buy imported goods in better price at the expense of the population of the exporting country" (Jandieri, 2010, p. 209).

On April 13-14, 2017, the Asian Development Bank (ADBI) Institute in Tokyo, Japan, hosted a two-day seminar on the 20th anniversary of the Asian Financial Crisis: Lessons, Challenges, and the Way Forward. At this two-day busy seminar which was broadcasted live, many interesting insights were expressed about the crisis twenty years ago, about the post-crisis period, including the year 2008 crisis, and the currency problems (socalled currency mismatch), which was one of the perpetrators in forming bubbles, and this is followed by a steady rise and the rupture of the crisis. Hyung Sung Shin, a representative of the Asian Development Bank, identified three main challenges:

- Global dollar funding and financial channel of exchange rates;

- Local currency bond markets and monetary policy challenges;

- Local currency bond markets and financial stability challenges. 
The strengthening of the local currency is associated with problems in terms of financial conditions, so it is a question of which system is better, an efficient regime or a bilateral US dollar? What mechanism plays the major role, additional risks, or agreed courses? How to determine the agreed value? He concludes that the global dollar is important to Asia as a major backdrop; In terms of monetary policy, the dollar exchange rate is a crucial financial condition and the local currency situation depends on the dollar exchange rate; In terms of financial stability, the local bonds' procyclicality is backed by cash. (ASDI, 2017, p. 28:03).

Understanding the existence of this problem Georgian National Bank tries to give some advices how to cope with it. For example, it offers to make hedging. "Various hedging instruments are used to minimize foreign exchange (FX) risk. The main purpose of FX hedging is to avoid the uncertainty associated with exchange rate fluctuations.

FX hedging enables importers and exporters to:

- Project cash flows in different currencies;

- Determine the prices that were foreseen in business plans;

- Maintain operational stability.” (Georgian National Bank, 2018).

Besides the scientists' and researchers' opinions it should be interesting to know what the economic subjects think about this issue, especially businessmen who continually make contracts with their partners and customers.

It is clear that changing of the money's value (non-stability of money) is one of the biggest problems for business subjects in developing countries. With the purpose of studying the businessmen's opinions about the problems of business, with focus on local currency, in Georgia there was done research in the period of January - April of 2019. Some interesting results of this research are given below.

\section{Hypothesis}

Fixed exchange rate relative to US dollar (or to Euro) is better for the economic subjects in Georgia.

\section{Methodology}

For this research the platform SurveyMonkey for sending emails was used. The research used structural questionnaire with 21 questions. Four out of 21 were questions for classification of having information about companies (are they local or international, in which sector of business, how big is size of the company, how long it operates, etc.)

It was very important that respondent had all needed information, therefore the questionnaire was sent to CEO members only (see the Figure 1).

The base of national statistic's service companies was used for the list of respondents. There were chosen 5000 companies to whom emails were sent and answers were received from $8.5 \%$ of them.

The limitation of the study is due to the fact that the percentage of respondents was relatively low. It can be assumed that the e-questionnaire was filled out mainly by the respondents for whom the topic in the questionnaire was relevant and who wanted to express an opinion on the issue. 


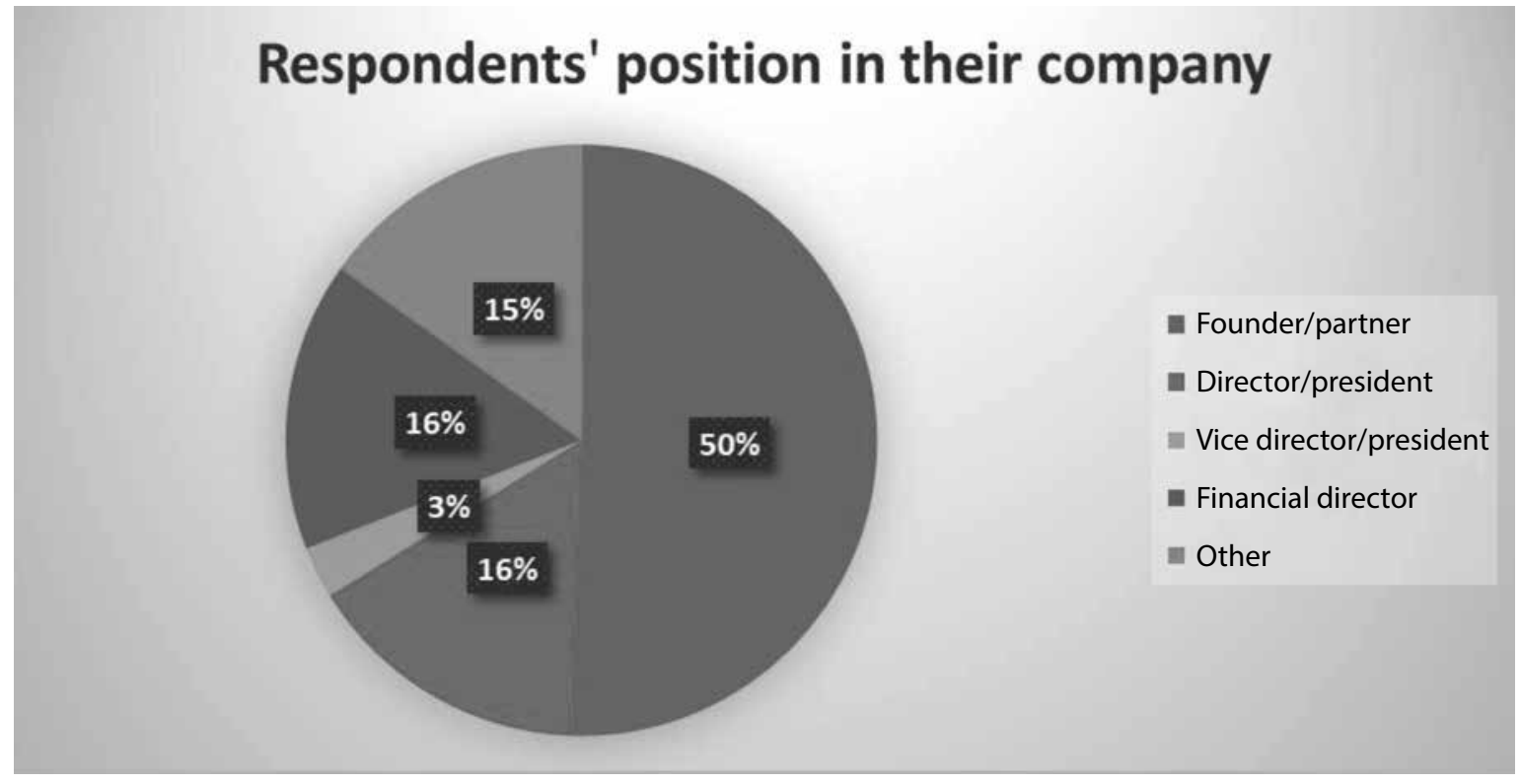

Figure 1. Respondents' positions in their companies

Source: author

The respondents were from companies differing by their sizes, time of existence and business specifics.

Distribution of companies by their size is provided in Figure 2, and distribution of companies by their operating time is provided respectively in Figure 3.

\section{Size of companies}

Big size company (annual income is more than 60 million GEL or employees more than 250).

Middle size company (annual income from 12 to 60 million GEL or employees from 50 to 250 ).

Small company (annual income from 1 to 12 million or employees from 10 to 50 )

Micro company (annual income less then 2 million GEL, employees up to 10)

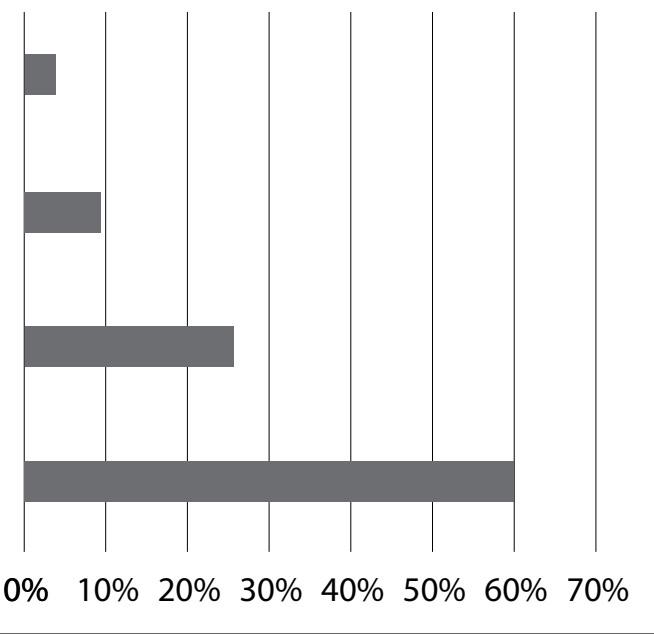

Figure 2. Size of representative companies

Source: author 


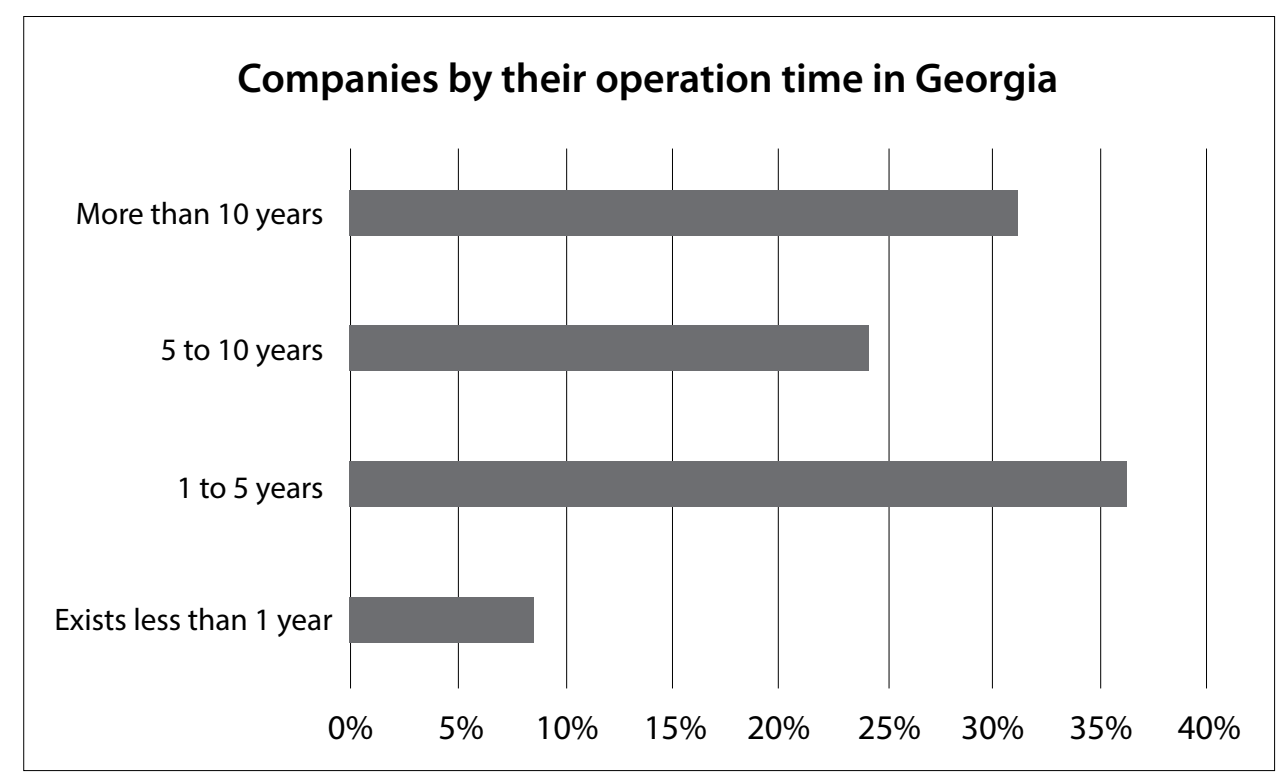

Figure 3. Companies by their operating time in Georgia.

Source: author

The companies were from different sectors of the economy. Here is a chart for companies by their business segments, Figure 4.

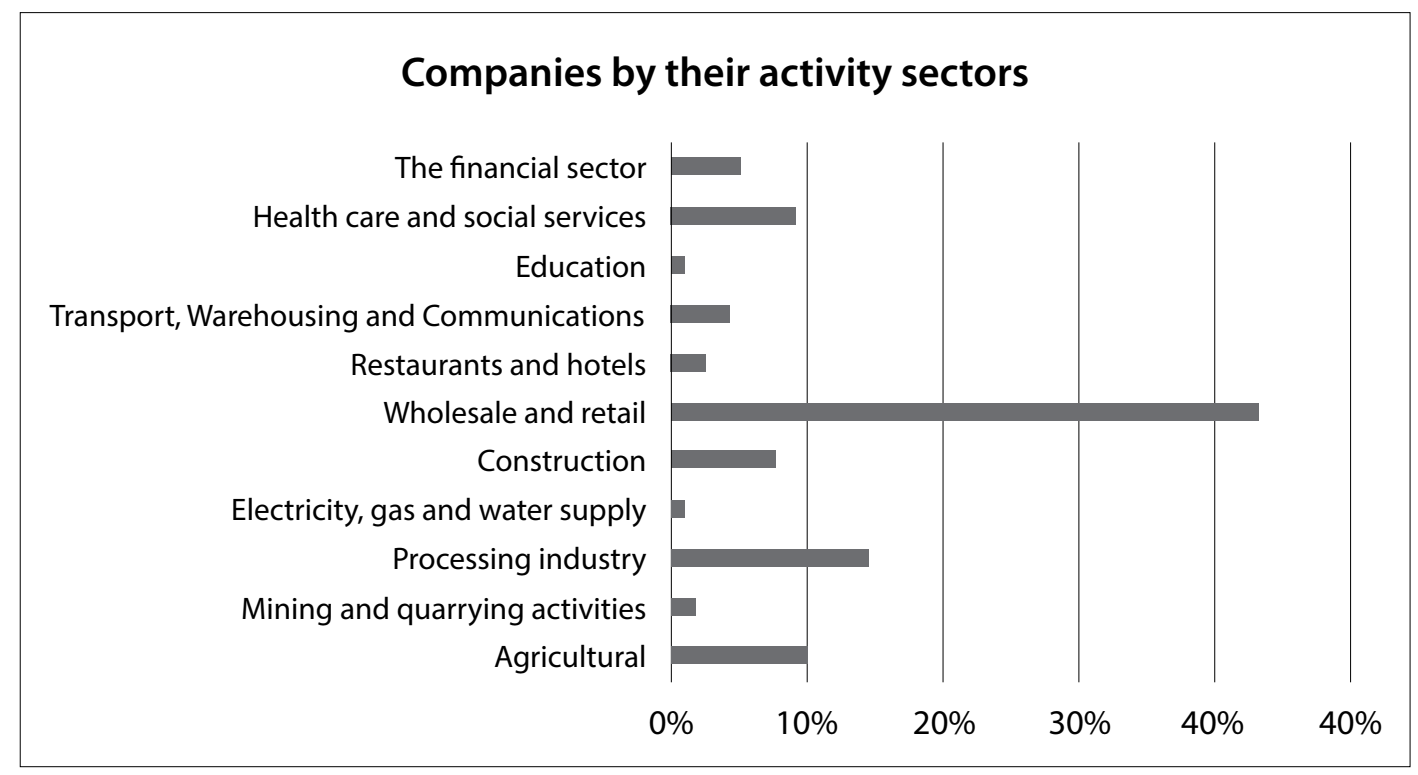

Figure 4. Companies by their activity sectors.

Source: author

\section{Statistical processing}

During this research the following methods of descriptive and inferential statistics were used: Frequency analysis, traction tables (contingency coefficient) comparison between independent groups by T-test.

The report provides statistically reliable results. For example, if the difference between the two groups of respondents is statistically reliable, it means that the difference between them is not due to random factors. In this case, the T-test or the coefficient of traction coefficient should be $<0.05$. 
The weighted-average method was used to prioritize the list of problems. For simplicity, the table below lists 5 problems that were prioritized by 300 respondents. We matched the priority signs to the weights. For example, if the respondent raised some problem in the first place, he / she is assigned a weight of 5 , if in the second place weight of 4, etc. Frequency of each priority was multiplied by weights and averaged. See Sample in table 1.

Table 1. Example of calculating the weighted average

\begin{tabular}{|c|c|c|c|c|c|c|c|c|c|}
\hline & A & B & $\mathrm{C}$ & $\mathrm{D}$ & $\mathrm{E}$ & $\mathrm{F}$ & $\mathrm{G}$ & $\mathrm{H}$ & I \\
\hline 1 & & \multicolumn{3}{|c|}{ Weight of priority: } & & & & & \\
\hline 2 & & p1 & $\mathrm{p} 2$ & p3 & $\mathrm{p} 4$ & $\mathrm{p} 5$ & total & & \\
\hline 3 & & 5 & 4 & 3 & 2 & 1 & & & \\
\hline 4 & & & & & & & & weigh & rage \\
\hline 5 & & \multicolumn{5}{|c|}{ Frequency of priorities: } & & & \\
\hline 6 & Problem 1 & 150 & 100 & 30 & 8 & 12 & 300 & 4,23 & $=$ SUMPRODUCT $(\$ B \$ 3: \$ F \$ 3 ; \mathrm{B} 6: \mathrm{F} 6) / \mathrm{G} 6$ \\
\hline 7 & Problem 2 & 120 & 80 & 20 & 10 & 70 & 300 & 3,57 & \\
\hline 8 & Problem 3 & 50 & 30 & 50 & 100 & 70 & 300 & 2,63 & \\
\hline 9 & Problem 4 & 15 & 20 & 25 & 120 & 120 & 300 & 1,97 & \\
\hline 10 & Problem5 & 10 & 20 & 30 & 120 & 120 & 300 & 1,93 & \\
\hline 11 & & & & & & & & & \\
\hline
\end{tabular}

Source: author

\section{Main findings of the study}

First question is how many companies operate with foreign currencies. The research shows that in Georgia most companies parallelly to Georgian Lari (GEL) operate with foreign currencies, and among latters majority use for their transactions US dollar, specifically. The chart is given in Figure 5.

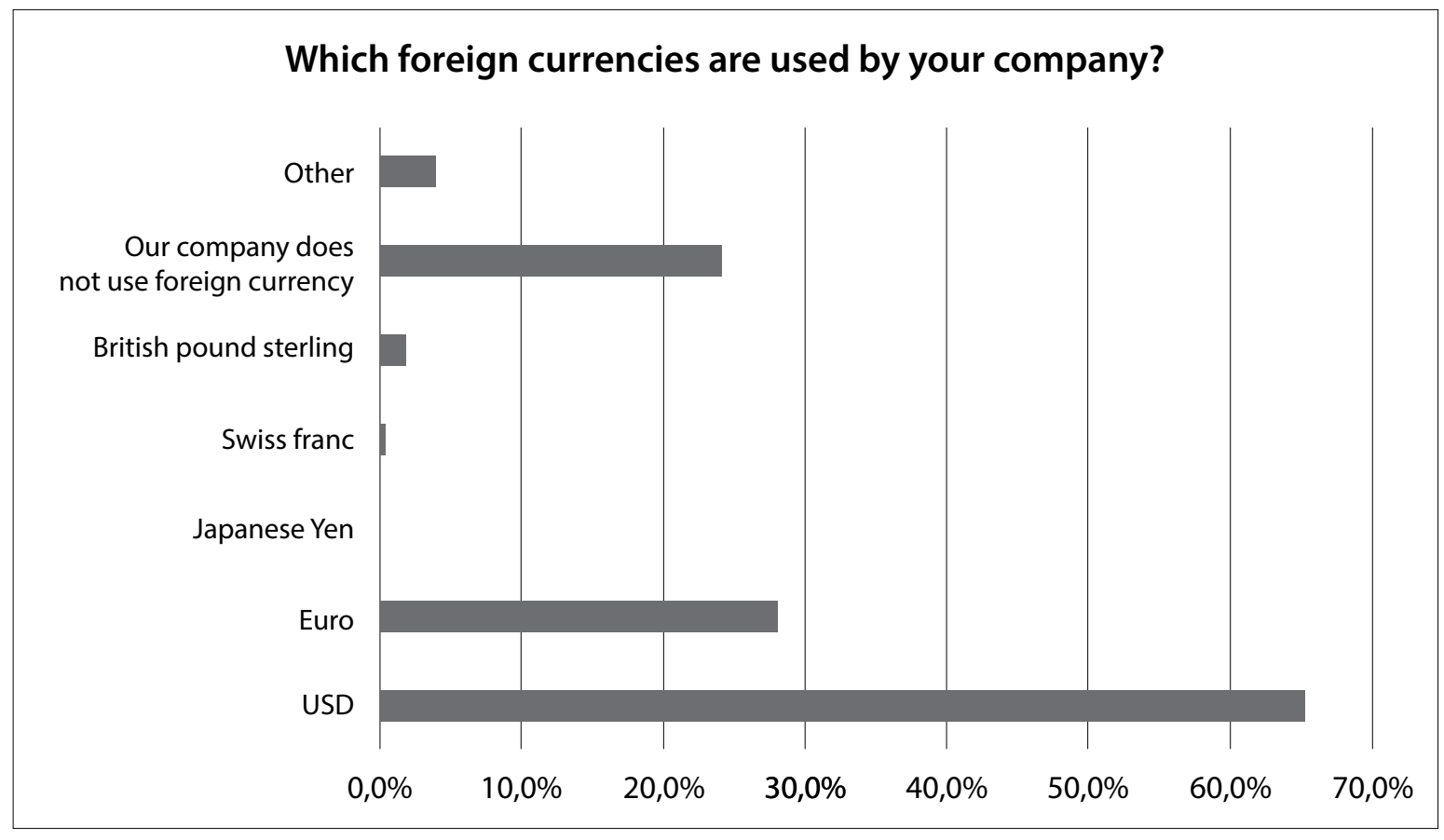

Figure 5. Which foreign currencies are used by companies in Georgia? 
On the question does your business depend on the currency exchange rate, only $3.7 \%$ answers that it does not depend on echange rate of national currency. Here is given separately companies which use foreign currency and companies which do not use foreign currencies. The chart is in Figure 6.

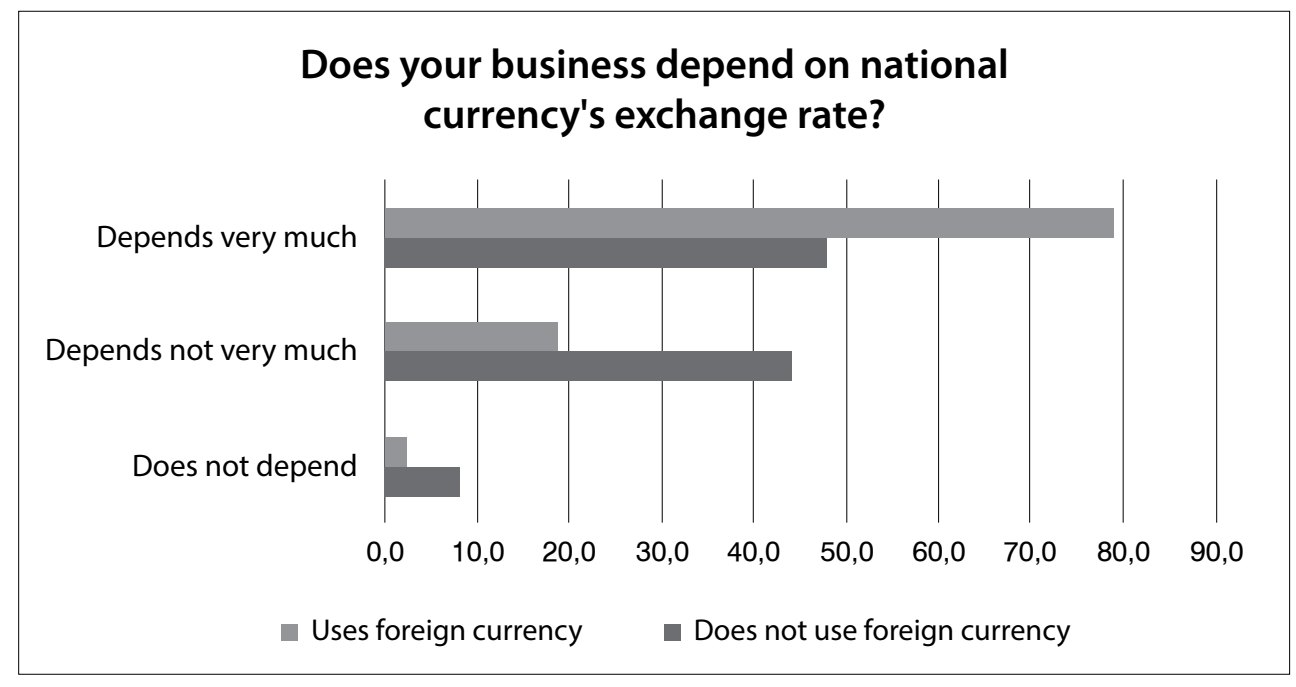

Figure 6. Business' dependence on currency's exchange rate.

Source: author

It is clear that the companies not using foreign currencies depend less on the exchange rate but in any case, we still have dependence for them and quite high - only $8.0 \%$ does not depend on the exchange rate.

Majority of the respondents think that the impact of non-stability of money is negative. Only $4.7 \%$ thinks that this devaluation has positive effect on their business (see the Figure 7).

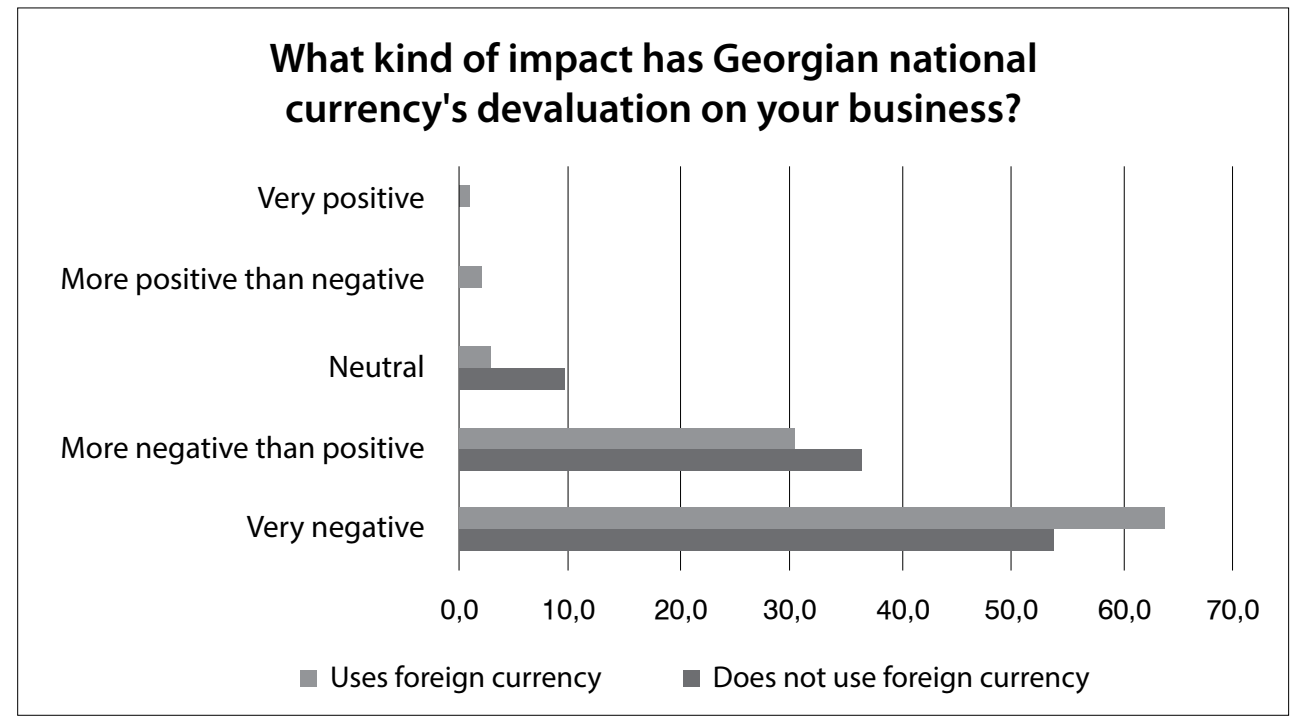

Figure 7. Impact of currency's devaluation on business in Georgia.

Source: author

Even for the companies who do not use foreign currencies the impact is negative, more than $90 \%$. Despite of this fact on the question if their companies have any strategy to insure safety against currency devaluation most of them say that there is no such insuring (Figure 8). 


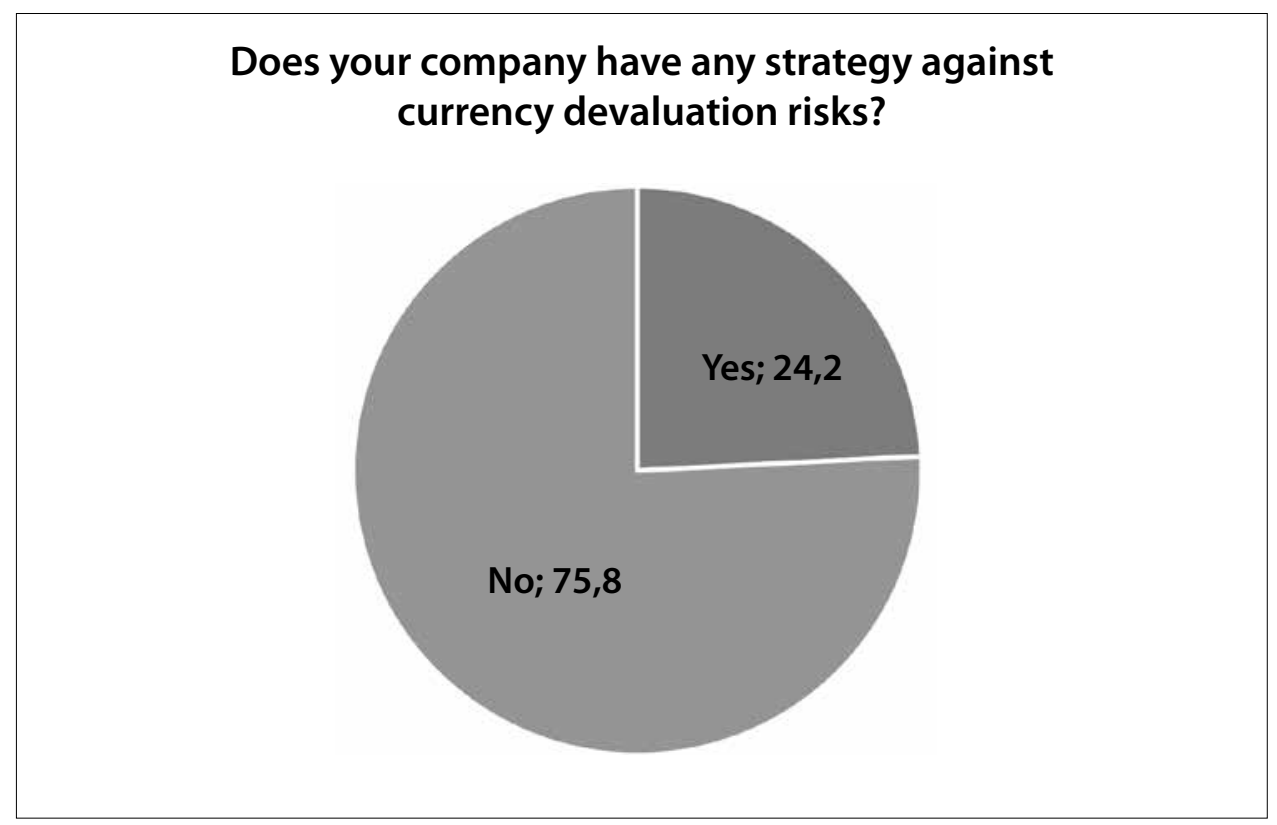

Figure 8. Existence of strategy against currency devaluation risks

Source: author

What do the companies do to secure themselves from this problem?

The answers of the respondents whose companies use foreign currency:

Increase their product's/service's price; $51.5 \%$

Decrease quantity of employees; $13.6 \%$

Seeking for raw materials in local market; $10.6 \%$

Looking for market abroad; $6.8 \%$

Only $4 \%$ of the respondents answered that they do hedging.

Combined chart is given in Figure 9.

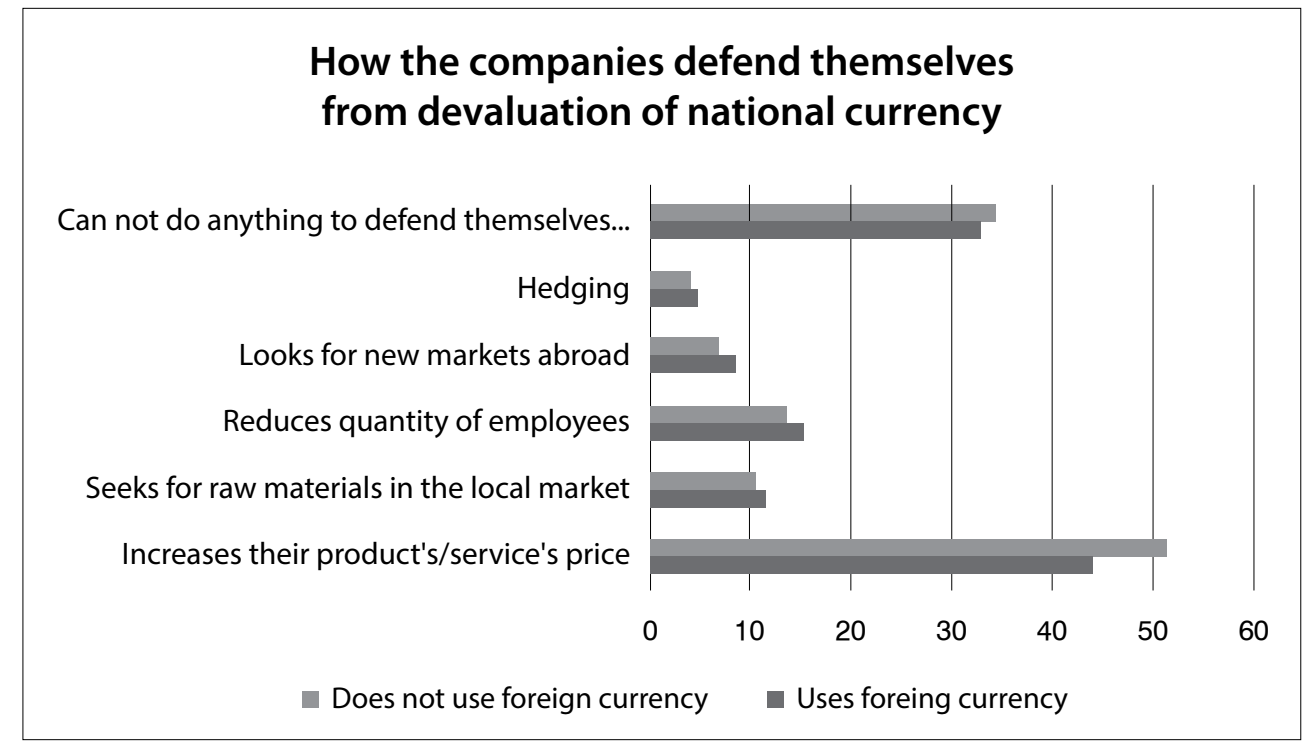

Figure 9. Companies' activity for defending themselves against devaluation of national currency. 
Beside the offered answers respondents gave some other options:

Reduce salaries;

Do more aggressive marketing;

Make contracts in foreign currencies;

Balancing actives and liabilities;

Reducing time for deferred payment;

Trade on online platforms;

Work with exchange rate given by national bank of Georgia;

Take credits in national currency;

Some respondents said that if the devaluation of national currency continues their company will stop working.

From the chart, below it is visible that the bigger companies have more possibilities to defend themselves from this problem (Figure 10).

\section{Companies who cannot defend themselves from national currency devaluation risk.}

Big size companies (annual income is more than 60 million GEL or emplyees more than 250)

Middle size company (annual income from 12 to 60 million GEL or employees from 50 to 250 )

Small company (annual income from 1 to 12 Million or employees from 10 to 50 )

Micro company (annual income less then 2 million GEL, employees up to 10)

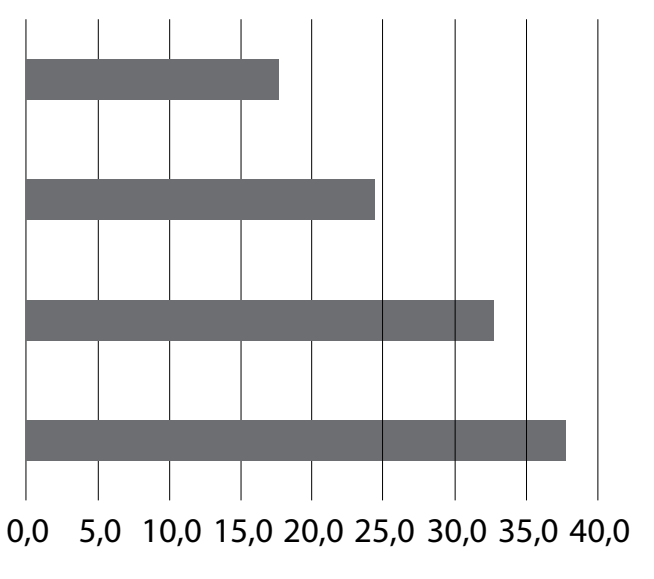

Figure 10. The companies cannot defend themselves from national currency devaluation risk. Source: author

There was question about perspectives of their business (Figure 11). 


\section{Is there possibility to develop your business in the current circumstances?}

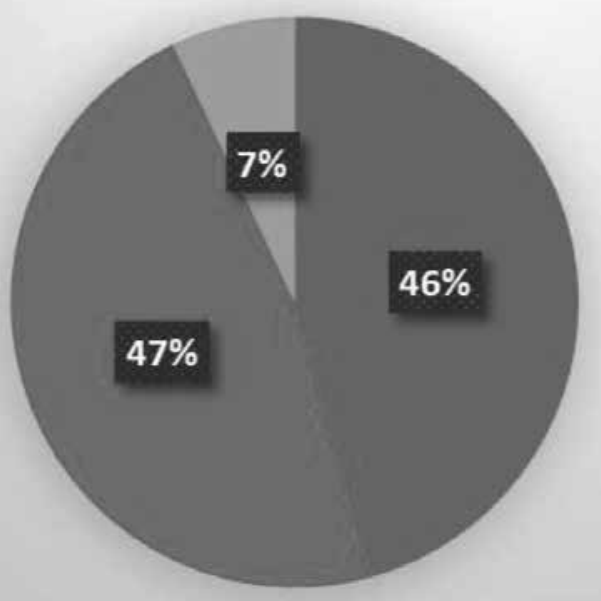

- Yes

no

Hard to answer

Figure 11. Expectation of their business developing in the current circumstances.

Source: author

On the same question for the next year the answers were as in Figure 12.

\section{During next year your business will:}

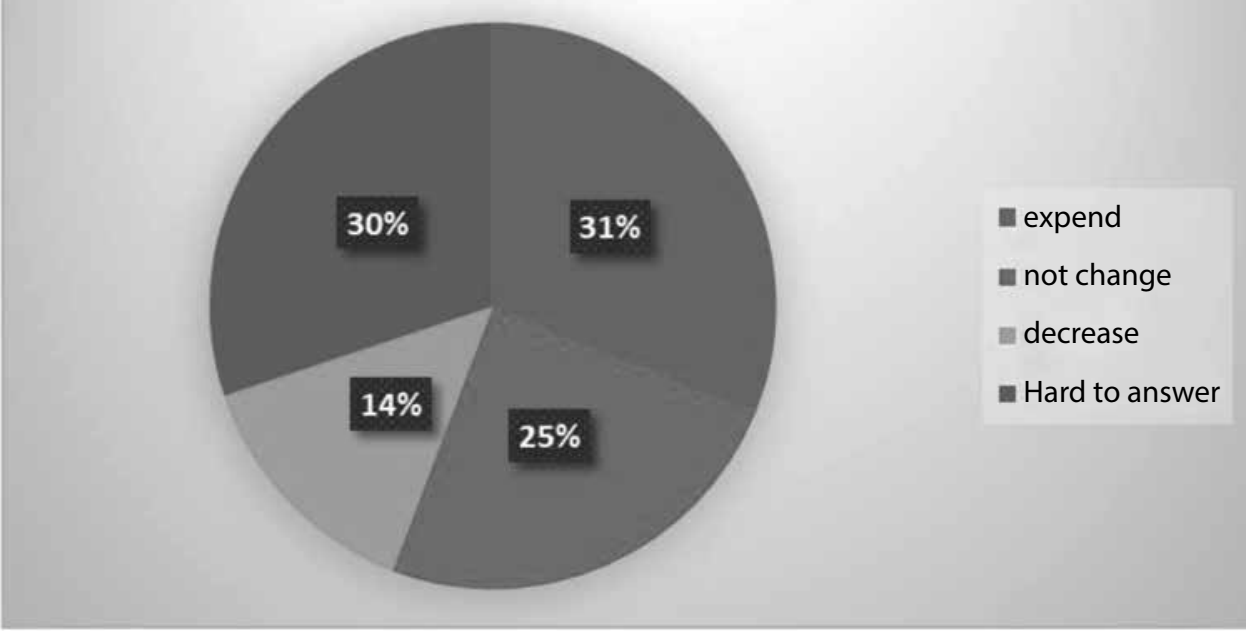

Figure 12. Expectation of their business developing in the current circumstances for the next year.

\section{Source: author}

And here is given one more chart with the same question only showing the situation of companies which use foreign currencies and which do not (Figure 13). 


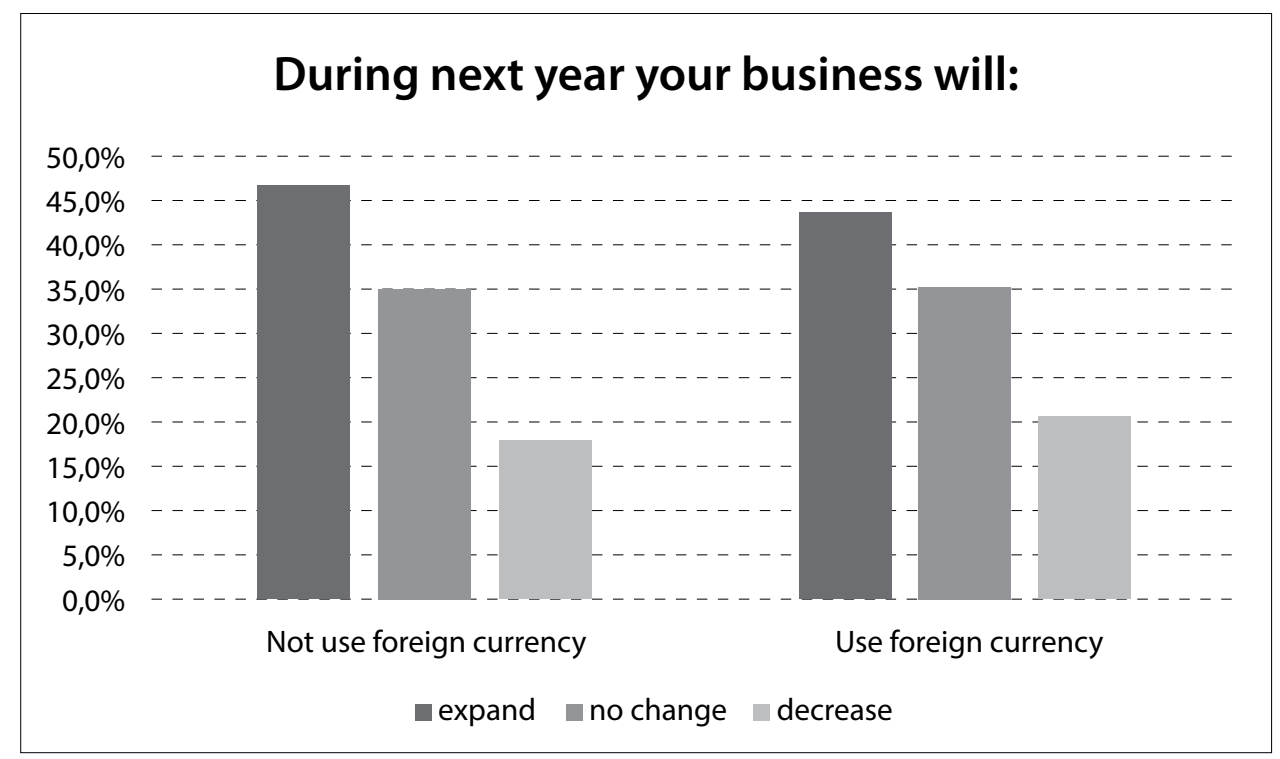

Figure 13. Expectation of their business developing in the current circumstances.

Source: author

The respondents were asked to rate the problems of business. The rate of each problem was calculated by weighted average. The results are given in the chart below (Figure 14). 


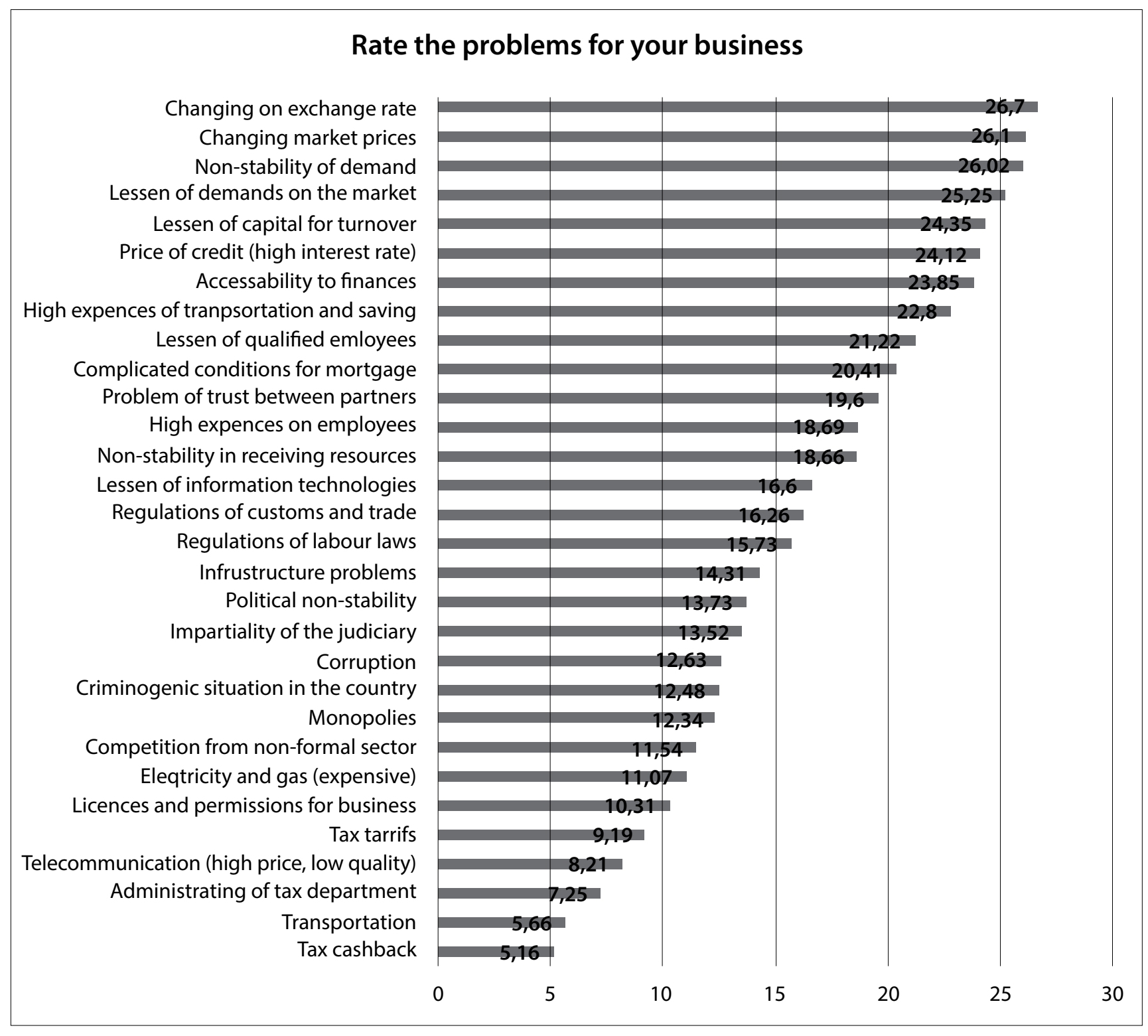

Figure 14. Rate of business problems

Source: author

We were giving to respondents' definition of currency regimes and asked to answer which of them could be better for Georgia. The results are given in the chart below (Figure 15). 


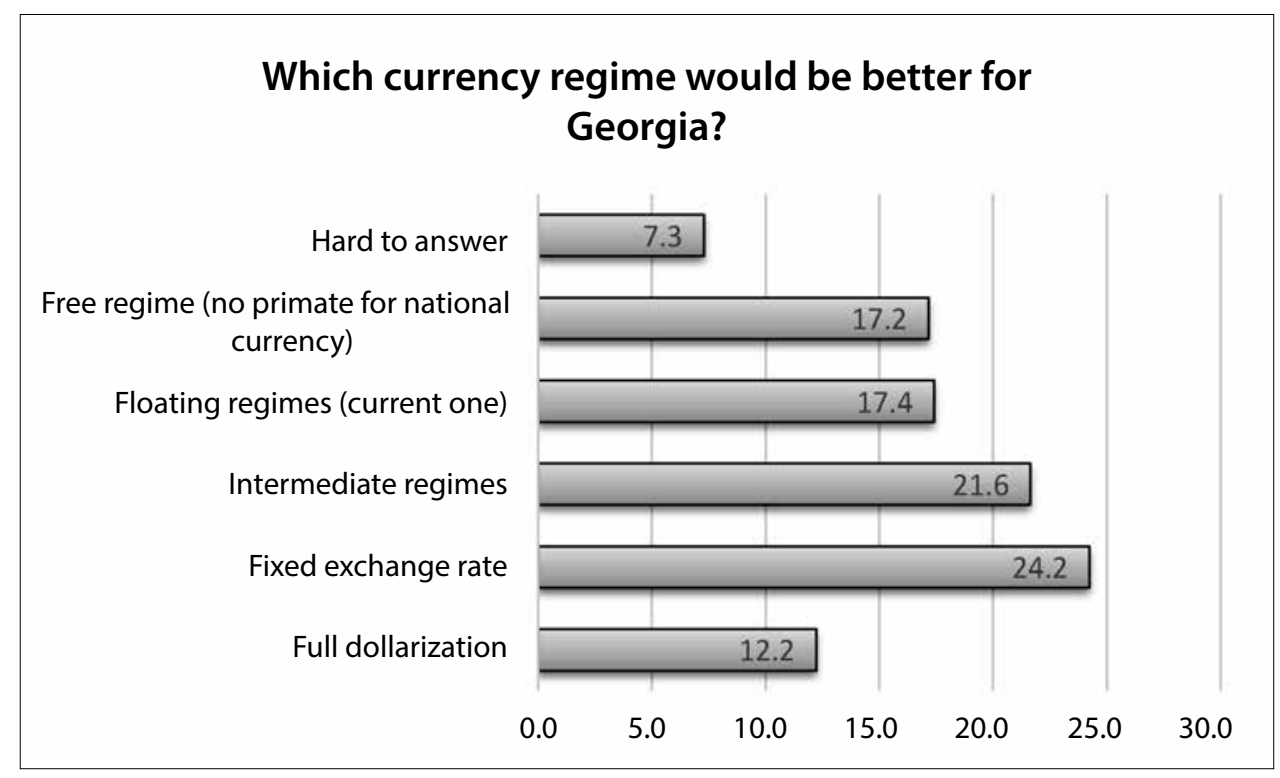

Figure 15. Which currency regime would be better for Georgia?

\section{Conclusion}

Our research shows that the currency regime is very sensitive question for every business and they have problems because of the risks of currency's value. Most businessmen think that the current regime for national currency is not suitable for Georgia and it would be better to have another one (more than $80 \%$ think so). Most of them believe that currency's fixed exchange rate would be better (as Steve Hanke advices), and the full dollarization is preferred only by $12.2 \%$ of respondents. But here should be mentioned that this outcome is a result of a mistake people often make: national currency is understood as an object of national identity. Excluding this factor, one could say that the percentage of respondents supporting the floating regime (17.4\%) would be reduced and share of others would be increased.

These results were anticipated as the tool of exchange needs to be durable but it is not. Even in the USA, if anyone looks for US dollar it is easy to see that durability is much less than it was even in $19^{\text {th }}$ century:

- Inflation in 1819 - 1919 was $12.50 \%$

- Inflation in 1919 - 2019 was 1371.48\% (CoinNews family, 2019).

Georgian Lari was issued in 1995. In the period of the existence of Georgian Lari the inflation of US dollar was $68.3 \%$ (CoinNews family, 2019) - quite big by itself. But for Georgian Lari for the same period of time inflation was $281,38 \%$ (Georgia, 2019).

Inflation in last 24 year for US dollar and Georgian Lari:

- US dollar inflated $68.3 \%$

- Georgian Lari inflated $281.38 \%$

This indicator shows too big inflation rate to save in this currency and consequently less trust to the currency from the side of business subjects, especially in case of non-stability of surrounding area in financial sector which does not give any guarantee that the inflation will continue flatly even tomorrow.

To conclude, Steven Hanke's advice that the strictly fixed exchange rate relative to US dollar (or to Euro) is better for the economy of Georgia seems to be wise as trust to US Dollar from the side of business subjects is greater than trust to Georgian currency. 
An important but open question is of course if the fixed currency regime is the best one or if there exists a possibility to choose another currency regime which is more suitable for the business subjects (and better for the economy of the country).

\section{References}

20 Years after the Asian Financial Crisis: Lessons, Challenges, and the Way Forward - day 1. 2017. Asian Development Bank Institute ASDI. Japan: ASDI, Asian Development Bank Institute.

Baiashvili, T. 2018. Optimal currency policy for the Georgian economy. Available at: https://www.nbg.gov.ge/uploads/journal/2015/2015_3/3.pdf

Baltgailis, J. 2019. The issues of increasing the effectiveness of teaching comparative economics, Insights into Regional Development 1(3): 190-199. https://doi.org/10.9770/ird.2019.1.3(1)

CoinNews family. 2019. US Inflation Calculator. Available at: http://www.usinflationcalculator.com/

Friedman, M. 2019. The Inflation Calculator. Available at: https://westegg.com/inflation/infl.cgi

Friedmen, M. 2002. Capitalism and Freedom. Tbilisi: Dilis Gazeti, Georgian edition.

Georgian National Bank, 2018. Foreign exchange risk and hedging. Available at: https://www.nbg.gov.ge/index.php?m=522\&lng=eng Greenspan, A., 2010. Gold and Economic Freedom. Librery of Liberty, Book VII, Money of Liberty / Georgian edition, pp. $143-147$.

Hayek, F. 2016. Choice in Currency: A Way to Stop Inflation. Why I am not conservative and other essays. Tbilisi: University of Georgia / Georgian edition, pp. 280-301.

Hanke Steve, S. K. 2010. Safe currency for Georgia. Tbilisi: Free Universities publishing house, Georgian edition.

Hoppe, H.H. 2010. Bank system, national governments and international polici: current economic discipline's sociological recosntruction. \%1Money of Liberty. Tbilisi: Tsignis Sakhelosno, Georgian edition.

Humbatova, S. I. O., Garayev, A.I.O., Tanriverdiev, S.M.O., Hajiyev, N.Q-O. 2019. Analysis of the oil, price and currency factor of economic growth in Azerbaijan, Entrepreneurship and Sustainability Issues 6(3): 1135-1153. http://doi.org/10.9770/jesi.2019.6.3(20)

Jandieri, G. 2010. Should We Trust to National Bank?. Librery of Liberty, Book VII, Money of Liberty / Georgian edition, pp. $205-212$. Keynes, J. M., 1924. A Tract on Monetary Reform. London: Macmillan and co., limited.

Kordík, M., Kurilovská, L. 2017. Protection of the national financial system from the money laundering and terrorism financing, Entrepreneurship and Sustainability Issues 5(2): 243-262. http://doi.org/10.9770/jesi.2017.5.2(7)

Limba, T., Stankevičius, A., Andrulevičius, A. 2019. Cryptocurrency as disruptive technology: theoretical insights, Entrepreneurship and Sustainability Issues 6(4): 2068-2080. http://doi.org/10.9770/jesi.2019.6.4(36)

NBG, 2019. National Bank of Georgia / Statisticx. Available at: https://www.nbg.gov.ge/index.php?m=304\&lng=eng

Salerno, J. 2010. Money, Sound and Unsound. Auburn: ISBN: 978-1-933550-93-0.

Šimonová, J, Čentéš, J., Beleš, A. 2019. Financial analysis of innovative forms of money, Entrepreneurship and Sustainability Issues 7(1): 69-80. http://doi.org/10.9770/jesi.2019.7.1(6)

Tsomaia, A. 2010. Modern Monetarism and Economic Freedom. Librery of Liberty, Book VII, Money of Liberty / Georgian edition, pp. 213-232. 
JOURNAL OF SECURITY AND SUSTAINABILITY ISSUES

ISSN 2029-7017 print/ISSN 2029-7025 online

Nodar CHINCHALADZE

ORCID ID: https://orcid.org/0000-0002-7539-3043

This work is licensed under the Creative Commons Attribution International License (CC BY) http://creativecommons.org/licenses/by/4.0/

cC) (i) Open Access

